\title{
Toxicological Profile for Metals in Alzheimer Disease
}

\author{
DANIEL DUDA-SEIMAN ${ }^{1}$, MARIA-ALEXANDRA MANOLACHE ${ }^{2}$, CORINA DUDA-SEIMAN ${ }^{2} *$ \\ 1"Victor Babeş" University of Medicine and Pharmacy Timişoara, 2 Eftimie Murgu Sq., 300041 Timişoara, Romania \\ ${ }^{2}$ West University of Timisoara, 4 Vasile Pârvan Blvd., 300223, Timişoara, Romania \\ ${ }^{3}$ Politehnica University of Timisoara, Hydrotechnical Engineering Dept., 2 Victoriei Sq., 300006, Timisoara, Romania
}

In this paper is presented the influence of contaminated-metals food on the Alzheimer disease. Alzheimer is a neurological disease which affects millions of people around the world. Over the time, the studies did not succeed to establish the cause that triggers the disease, but there are several factors that sustained its occurrence. One of this risk factors are the toxic metals found in the human body. The intoxication might be caused by dietary. Metals like $\mathrm{Cd}(\mathrm{II}), \mathrm{Pb}(\mathrm{II}), \mathrm{Hg}(\mathrm{II}), \mathrm{Zn}(\mathrm{II})$ don't have a known biological role and the exposure to these metals is associated with neurodegenerative disorders.

Keywords: heavy metals, Alzheimer risk, dietary, fish, vegetables, fruits

The Alzheimer disease is the most common type of dementia with a multitude of clinic symptoms. The studies proved the existence of several risk factors responsible for the disease triggering, for example: age, sex, medical history and genetic factors (gene modification). The Alzheimer disease has clinical manifestation such as memory loss, insomnia, anxiety which lead to cognitive decline $[1,2]$. This disease is characterized by structural and functional damage at the Central Nervous System. Gradually the neuronal degradation occurs which is caused by the extracellular deposit of betaamyloid protein and the presence of hyperphosphorylated protein [3, 4]. The genetic risk factor plays an essential role in pathogenesis disease [5]. APOE is one of the involved gene. The gene mutation for apolipoprotein $\mathrm{E}$ is predictive for Alzheimer. APOE is also involved in the beta-amyloid metabolism [6]. Discovering the main root cause of the Alzheimer disease would be a significant step for preventing it. Oxidative stress causes oxidative lesions and also involved the highlevel accumulation of reactive oxygen. Exposure to metals cause the increase of oxidative stress in brain cells [7]. The neurodegeneration and the oxidative stress are consequences of toxic metals exposure [8]. The neuronal activity is influenced by metals. $\mathrm{Cu}$ (II), $\mathrm{Zn}$ (II), Fe (II) ions are the most relevant influencers regarding oxidative stress. These ions are provided during the maturation and folding of the proteins [9]. The fact that these before mentioned metals are signs of the Alzheimer disease has been documented already. The human body gets poisoned by toxic metals due to several factors. Pollution is one of them and it includes water pollution, air pollution and soil pollution which interference with human health. Industrial and chemical pollution affects population indirectly through air, food and water.

The neurodegenerative diseases are caused by etiological factors resulted from the interaction of lifestyle and environmental factors and thus the exposure of metal-containing compounds. Several metals are mainly cadmium, cobalt, copper, and aluminum which provoke neurotoxicity [10,11]. Cadmium involves neurological disorders of the central nervous system (CNS). The main component of CNS is astrocytes - supporting cells are resistant to Cd(II). Cadmium exposure induces apoptotic and necrotic cellular death [12]. Studies have shown that the glutamatergic system may be used as a potential biomarker for neurotoxic action of heavy metals in humans [13]. Cobalt may be responsible for regulation the expression of $\beta$-amyloid precursor protein (APP) [14]. The copper has a major role in neuronal myelination [15]. An imbalance or other breakdown of copper homeostasis system is associated with neurological disease such as Alzheimer disease [16]. It is widely accepted that increased extracellular copper levels contribute to neuronal pathogenic process by increasing the production of deleterious ROS (Reactive Oxygen Species) [17]. Copper dysregulation is implicated in the phosphorylation and aggregation of tau, the main component of neurofibrillary tangles, which is a defining pathological hallmark of Alzheimer disease [18]. Fruits and vegetables are predisposed to heavy metals contamination. The main source of food contamination is the soil, beside this one, packaging material, food handlers, animals, birds, insects, rodents, air, dust, water, garbage and sewage are also a cause. The soil is the primary sink for toxic

*email: cori_mam@yahoo.com 
metals [19]. In the European Union the maximum levels for certain contaminants in foodstuffs are mentioned in the European Commission regulation no 1881/2006. Dietary is the main exposure risk of the human body towards heavy metal contamination that can cause illness due to food chain transfer. Fruits and vegetables are an important component of the dietary for the essential intake of fibers, minerals and other nutrients. Metals like $\mathrm{Cr}$ (III), $\mathrm{Cu}$ (II), $\mathrm{Zn}$ (II) might have neurological involvement causing headache when it exceeds normal values [20, 21]. Tomato fruits (Solanum lycopersicum) are the most consumed food around the world. Tomato plants absorb greater amounts of heavy metals, especially Cd (II) [22]. Another food source is the fish, because of its rich content of carbohydrates, animal protein, fatty acids, polyunsaturated fatty acids and vitamins. Besides his benefic aspects, the fish is contaminated with heavy metals such as $\mathrm{Cd}(\mathrm{II}), \mathrm{Cu}(\mathrm{II}), \mathrm{Pb}(\mathrm{II}), \mathrm{Zn}(\mathrm{II})$. The consumption of $\mathrm{Pb}$ (II) affects the human health inducing fatigue, irritability, coma encephalopathy, brain damage, nervous-system dysfunctions. These last two examples form a bond between contaminated metals food and Alzheimer [23]. Strawberry consumption benefits health thanks to the antioxidant capacity of the bioactive compounds. It also has protective effects against oxidative stress generated by doxorubicin (chemotherapeutical agent) [24].

\section{Experimental part}

The following experiments to be described in later have the purpose of determining the metal content of food was achieved by three methods. Subjects exposed to the experiments were represented by several fruits - orange (Citrus sinensis), strawberry (Fragaria ananassa), avocado (Persea Americana), pomegranate (Punica granatum) and tomato (Solanum lycopersicum) - were bought from a supermarket in Timisoara. The first method involved the determination of the metal content of the product by extraction into water. The fruits were washed, put each one in pots and added $130 \mathrm{ml}$ of water. These fruits were subjected to thermal shock on electric hotplate. After boiling, were left to cool and the liquid resulting from the boiling is filtered and poured into 7 containers corresponding to each food. For orange has been boiled both the peel and the pulp. We also used this method for fish. The samples thus obtained were subjected to spectrophotometric atomic absorption analysis using the atomic absorption spectrophotometer VARIAN spectra AAS 280FS. The second method of analyzing the metal content was carried out by extraction in hydrochloric acid with a $\mathrm{pH}$ similar to that in the stomach (1.5 - 3.5) to simulate the way are absorbed the food components. In this experiment, each fruit was introduced into the blender and hydrochloric acid $(\mathrm{HCl})$ was added each time $(15 \mathrm{~mL} \mathrm{HCl})$. After that the samples were placed in seven containers corresponding to each food. The samples were left for 24 hours to separate the solid phase from the liquid phase and after 24 hours were filtered. The filtration was carried out under reduced pressure, in vacuum and the phase separation was accelerated by creating a pressure difference between the two components of the filtrate. A water tube was connected to the filter vessel for a lower pressure. It used a porcelain funnel Buchner with the perforations on which the filter paper was placed. The funnel is tightly attached with a rubber stopper to the hopper vessel that is attached to a safety vessel. The water pipe is connected to a water source and to the safety vessel. At the opening of the water a sub pressure is created in the safety vessel and implicitly in the hopper vessel which produces suction at the surface of the paper. This increased the filtering speed. The samples thus obtained were subjected to spectrophotometric atomic absorption analysis. The third method consisted in determining the metal content obtained by calcination and then mineralization with the aqua regia. By this method it was possible to simulate the metabolism of metals in the body from absorption to metabolism and eventually to elimination. The samples were calcined for 6 hours at $550^{\circ} \mathrm{C}$, with a 10 degree/minute level in the air, using the LHT407GN Nabertherm Furnaces furnace. The samples were then mineralized according to ISO 11047/1998. Thus, weigh about $1 \mathrm{~g}$ of soil with an accuracy of $0.001 \mathrm{~g}$ in a $250 \mathrm{~mL}$ reaction vessel. Add, with stirring, $10 \mathrm{~mL}$ of hydrochloric acid followed by $5 \mathrm{~mL}$ of nitric acid drop by drop if necessary. The temperature of the reaction mixture slowly rises and then allowed to cool. The insoluble residue in the reaction vessel is allowed to settle. The relatively free sedimentation supernatant obtained by decantation is carefully passed through filter paper, collecting the filter in a $100 \mathrm{~mL}$ volumetric flask. Pass all the initial extract from the reaction vessel through the filter paper, then wash the insoluble residue from the filter paper. The samples thus obtained were subjected to spectrophotometric atomic absorption analysis using the atomic absorption spectrophotometer VARIAN spectra AAS 280FS.

\section{Results and discussions}

Following the three experiments, the presence of more or less beneficial metals was indicated (Cu(II), $\mathrm{Zn}$ (II), $\mathrm{Fe}$ (II), $\mathrm{Cd}(\mathrm{II}), \mathrm{Pb}(\mathrm{II}), \mathrm{Cr}(\mathrm{III}), \mathrm{Hg}(\mathrm{II}), \mathrm{Mn}(\mathrm{II})$ ) according to the three tables (Table 1, Table 2, Table 3). Table 1 corresponds to the first method, Table 2 corresponds to the second method and Table 3 corresponds to the third method. 
Table 1

METALS CONTENT OBTAINED BY EXTRACTION INTO WATER

\begin{tabular}{|c|c|c|c|c|c|c|c|c|c|c|c|c|}
\hline Sample & $\begin{array}{l}\mathrm{Ca}^{2+}, \\
\mathrm{mg} / \mathrm{Kg} \\
\text { d.w. }\end{array}$ & $\begin{array}{l}\mathrm{Mg}^{2+}, \\
\mathrm{mg} / \mathrm{Kg} \\
\text { d.w. }\end{array}$ & $\begin{array}{c}\mathrm{Na}^{+}, \\
\mathrm{mg} / \mathrm{Kg} \\
\text { d.w. }\end{array}$ & $\begin{array}{c}\mathrm{K}^{+}, \\
\mathrm{mg} / \mathrm{Kg} \\
\text { d.w. }\end{array}$ & $\begin{array}{l}\mathrm{Cu}^{2+}, \\
\mathrm{mg} / \mathrm{Kg} \\
\text { d.w. }\end{array}$ & $\begin{array}{c}\mathrm{Zn}^{2+} \\
\mathrm{mg} / \mathrm{Kg} \\
\text { d.w. }\end{array}$ & $\begin{array}{l}\text { Fetot, } \\
\mathrm{mg} / \mathrm{Kg} \\
\text { d.w. }\end{array}$ & $\begin{array}{l}\mathrm{Cd}^{2+}, \\
\mathrm{mg} / \mathrm{Kg} \\
\text { d.w. }\end{array}$ & $\begin{array}{l}\mathrm{Pb}^{2+}, \\
\mathrm{mg} / \mathrm{Kg} \\
\text { d.w. }\end{array}$ & $\begin{array}{l}\mathrm{Cr}_{\text {tot, }} \\
\mathrm{mg} / \mathrm{Kg} \\
\text { d.w. }\end{array}$ & $\begin{array}{l}\mathrm{Hg}^{2+}, \\
\mathrm{mg} / \mathrm{Kg} \\
\text { d.w. }\end{array}$ & $\begin{array}{l}\mathrm{Mn}^{2+} \text {, } \\
\mathrm{mg} / \mathrm{Kg} \\
\text { d.w. }\end{array}$ \\
\hline $\begin{array}{c}\text { Fish } \\
\text { salmon }\end{array}$ & 8.98 & 1.23 & 2.23 & 13.12 & 0.21 & 1.23 & 3.61 & $<0.01$ & $<0.01$ & 0.54 & $<0.01$ & 0.36 \\
\hline $\begin{array}{l}\text { Pomegr } \\
\text { ade }\end{array}$ & 6.98 & 1.76 & 0.12 & 22.21 & 0.82 & 1.42 & 0.76 & $<0.01$ & $<0.01$ & 0.09 & $<0.01$ & 1.42 \\
\hline $\begin{array}{c}\text { Avocad } \\
0 \\
\end{array}$ & 1.32 & 2.87 & 0.09 & 44.31 & 0.53 & 1.39 & 3.52 & $<0.01$ & $<0.01$ & 0.19 & $<0.01$ & 1.59 \\
\hline Orange & 4.98 & 2.12 & 0.12 & 36.98 & 0.64 & 0.54 & 1.67 & $<0.01$ & $<0.01$ & 0.21 & $<0.01$ & 0.49 \\
\hline $\begin{array}{c}\text { Strawb } \\
\text { erry }\end{array}$ & 0.98 & 1.78 & 11.12 & 15.98 & 0.12 & 0.68 & 2.34 & 1.43 & $<0.01$ & 0.12 & $<0.01$ & 14.2 \\
\hline Tomato & 0.23 & 0.01 & 0.13 & 27.5 & 0.18 & 1.89 & 0.45 & $<0.01$ & $<0.01$ & $<0.01$ & $<0.01$ & 0.13 \\
\hline
\end{tabular}

Table 2

METALS CONTENT OBTAINED BY EXTRACTION CHLORHYDRIC ACID

\begin{tabular}{|c|c|c|c|c|c|c|c|c|c|c|c|c|}
\hline Sample & $\begin{array}{l}\mathrm{Ca}^{2+} . \\
\mathrm{mg} / \mathrm{Kg} \\
\text { d.w. }\end{array}$ & $\begin{array}{l}\mathrm{Mg}^{2+} . \\
\mathrm{mg} / \mathrm{Kg} \\
\text { d.w. }\end{array}$ & $\begin{array}{c}\mathrm{Na}^{+} . \\
\mathrm{mg} / \mathrm{Kg} \\
\text { d.w. }\end{array}$ & $\begin{array}{c}\mathrm{K}^{+} . \\
\mathrm{mg} / \mathrm{Kg} \\
\text { d.w. }\end{array}$ & $\begin{array}{c}\mathrm{Cu}^{2+} \text {. } \\
\mathrm{mg} / \mathrm{Kg} \\
\text { d.w. }\end{array}$ & $\begin{array}{c}\mathrm{Zn}^{2+} \text {. } \\
\mathrm{mg} / \mathrm{Kg} \\
\text { d.w. }\end{array}$ & $\begin{array}{c}\text { Fetot. } \\
\mathrm{mg} / \mathrm{Kg} \\
\text { d.w. }\end{array}$ & $\begin{array}{l}\mathrm{Cd}^{2+} . \\
\mathrm{mg} / \mathrm{Kg} \\
\text { d.w. }\end{array}$ & $\begin{array}{l}\mathrm{Pb}^{2+} \text {. } \\
\mathrm{mg} / \mathrm{Kg} \\
\text { d.w. }\end{array}$ & $\begin{array}{l}\mathrm{Cr}_{\text {tot. }} \\
\mathrm{mg} / \mathrm{Kg} \\
\text { d.w. }\end{array}$ & $\begin{array}{l}\mathrm{Hg}^{2+} \text {. } \\
\mathrm{mg} / \mathrm{Kg} \\
\text { d.w. }\end{array}$ & $\begin{array}{c}\mathrm{Mn}^{2+} \text {. } \\
\mathrm{mg} / \mathrm{Kg} \\
\text { d.w. }\end{array}$ \\
\hline $\begin{array}{c}\text { Fish } \\
\text { salmon }\end{array}$ & 9.32 & 1.89 & 2.89 & 14.98 & 1.98 & 12.45 & 35.9 & $<0.01$ & $<0.01$ & 4.39 & $<0.01$ & 3.45 \\
\hline $\begin{array}{c}\text { Pomegr } \\
\text { ade }\end{array}$ & 7.43 & 1.12 & 0.56 & 23.98 & 7.21 & 14.19 & 6.58 & 0.045 & $<0.01$ & 1.78 & $<0.01$ & 13.56 \\
\hline $\begin{array}{c}\text { Avocad } \\
0 \\
\end{array}$ & 0.91 & 2.03 & 0.12 & 45.78 & 5.34 & 13.64 & 34.9 & $<0.01$ & $<0.01$ & 2.56 & $<0.01$ & 16.12 \\
\hline Orange & 5.54 & 2.21 & 0.23 & 37.01 & 6.34 & 4.95 & 18.9 & $<0.01$ & $<0.01$ & 2.45 & $<0.01$ & 5.34 \\
\hline $\begin{array}{c}\text { Strawb } \\
\text { erry }\end{array}$ & 0.78 & 1.67 & 11.32 & 16.89 & 1.23 & 6.98 & 24.55 & 13.6 & $<0.01$ & 3.12 & $<0.01$ & 148.5 \\
\hline Tomato & 0.56 & 0.009 & 0.098 & 28.9 & 1.98 & 18.9 & 3.69 & $<0.01$ & $<0.01$ & $<0.01$ & $<0.01$ & 1.12 \\
\hline
\end{tabular}

Table 3

METALS CONTENT OBTAINED BY CALCINATION AND MINERALIZATION WITH AQUA REGIA

\begin{tabular}{|c|c|c|c|c|c|c|c|c|c|c|c|c|}
\hline Sample & $\begin{array}{c}\mathrm{Ca}^{2+} . \\
\mathrm{mg} / \mathrm{Kg} \\
\text { d.w. }\end{array}$ & $\begin{array}{l}\mathrm{Mg}^{2+} . \\
\mathrm{mg} / \mathrm{Kg} \\
\text { d.w. }\end{array}$ & $\begin{array}{l}\mathrm{Na}^{+} . \\
\mathrm{mg} / \mathrm{Kg} \\
\text { d.w. }\end{array}$ & $\begin{array}{c}\mathrm{K}^{+} . \\
\mathrm{mg} / \mathrm{Kg} \\
\text { d.w. }\end{array}$ & $\begin{array}{c}\mathrm{Cu}^{2+} . \\
\mathrm{mg} / \mathrm{Kg} \\
\text { d.w. }\end{array}$ & $\begin{array}{c}\mathrm{Zn}^{2+} \\
\mathrm{mg} / \mathrm{Kg} \\
\text { d.w. }\end{array}$ & $\begin{array}{l}\mathrm{Fe}_{\text {tot. }} \\
\mathrm{mg} / \mathrm{Kg} \\
\text { d.w. }\end{array}$ & $\begin{array}{c}\mathrm{Cd}^{2+} . \\
\mathrm{mg} / \mathrm{Kg} \\
\text { d.w. }\end{array}$ & $\begin{array}{l}\mathrm{Pb}^{2+} \text {. } \\
\mathrm{mg} / \mathrm{Kg} \\
\text { d.w. }\end{array}$ & $\begin{array}{l}\mathrm{Cr}_{\text {tot. }} \\
\mathrm{mg} / \mathrm{Kg} \\
\text { d.w. }\end{array}$ & $\begin{array}{l}\mathrm{Hg}^{2+} . \\
\mathrm{mg} / \mathrm{Kg} \\
\text { d.w. }\end{array}$ & $\begin{array}{c}\mathrm{Mn}^{2+} . \\
\mathrm{mg} / \mathrm{Kg} \\
\text { d.w. }\end{array}$ \\
\hline $\begin{array}{c}\text { Fish } \\
\text { salmon }\end{array}$ & 29.5 & 11.22 & 28.11 & 159.71 & 20.0 & 126 & 361.8 & $<0.01$ & $<0.01$ & 49.31 & $<0.01$ & 30.03 \\
\hline $\begin{array}{l}\text { Pomegr } \\
\text { ade }\end{array}$ & 10.8 & 13.33 & 4.95 & 249.3 & 76.0 & 141 & 68 & 4.72 & $<0.01$ & 18.11 & $<0.01$ & 133.07 \\
\hline $\begin{array}{c}\text { Avocad } \\
0\end{array}$ & 4.9 & 20.5 & 1.17 & 462.6 & 53.0 & 136 & 359.7 & $<0.01$ & $<0.01$ & 22.56 & $<0.01$ & 166.28 \\
\hline Orange & 53.0 & 25.6 & 2.97 & 367.5 & 65.14 & 49 & 197.4 & $<0.01$ & $<0.01$ & 29.45 & $<0.01$ & 51.68 \\
\hline $\begin{array}{c}\text { Strawb } \\
\text { erry }\end{array}$ & 8.6 & 19.09 & 12.91 & 172.4 & 10.0 & 73 & 255 & 139.53 & $<0.01$ & 30.81 & $<0.01$ & 1497.67 \\
\hline Tomato & 6.2 & 1.76 & 1.285 & 296.3 & 15.43 & 193 & 39 & $<0.01$ & $<0.01$ & $<0.01$ & $<0.01$ & 11.03 \\
\hline
\end{tabular}

The metals found in experiments can become harmful to the body due to the inability to remove them and thus accumulate in various organs including the brain and lead to many diseases including Alzheimer disease. Further. the interpretation of the obtained results will be based on the tables [25]. Copper. metal found after spectrophotometric analysis is recommended by specialists to be consumed in small quantities $0.9 \mathrm{mg} / \mathrm{day}$. Through the consumption of copper-rich foods can be triggered a number of changes in the whole body that can endanger the health (e.g. modulating aggregation of the $\beta$-amyloid protein and favoring its maturation. increasing toxicity). As can be seen in the above tables. the diet should be balanced. not to consume large amounts of a particular food (e.g.: pomegranate contains a fairly large amount of copper) [26, 27].

Zinc is an important metal of the body. The daily requirement for zinc recommended for health is $10-15 \mathrm{mg} / \mathrm{day}$. With regard to the influence of zinc on Alzheimer's disease. it has been observed that the zinc metabolism is altered with aberrant $\mathrm{Zn}$ accumulation in amyloid plaques. The $\beta$-amyloid peptide has zinc binding sites and the zinc is the only metal REV.CHIM.(Bucharest) $\bullet 1 \bullet$ no. $1 \bullet 2020$ 
that can precipitate $\beta$-amyloid. Thus. the binding of zinc to $\beta$-amyloid plays an important role in the formation of amyloid plaques and implicitly in Alzheimer's disease. According to analyzes on the content of metals in food. tomato shows the largest amount of zinc in the food examined [28. 29]. Iron. essential for the body. who's daily recommended intake is 10$15 \mathrm{mg}$. Iron deficiency causes cognitive impairment. Studies have shown that the amyloid-Fe ${ }^{2+}$ complex is responsible for oxidative stress (a risk factor for Alzheimer's disease). According to the results of the food analysis. the fish offer the highest contribution of Fe(II). It should be consumed regularly in moderate amounts to not affect the health of the body [30]. Cadmium is a metal with severe health risks. The daily recommended intake from diet varies between $0.002-0.2 \mathrm{mg}$. This metal becomes toxic to the body if the admissible values are exceeded. In terms of adverse health effects. cadmium causes a decrease in concentration and affects the health of memory. Also induces neuronal death. The results of the experiments indicate that pomegranate and strawberry have a higher content of $\mathrm{Cd}$ (II) which means consuming them with caution [31]. Chromium is an essential mineral for the metabolism of glucose. but becomes toxic in large quantities. Insulin affects glucose metabolism and is thus associated with memory impairment. The daily dose is $0.055-0.066 \mathrm{mg}$. As can be seen in the tables. the fish is again the first in terms of increased content of metals [32]. Lead is non-essential metal to the body. The tolerated dose of ingested lead is $3 \mathrm{mg} /$ day. Once in the body in quantities greater than the admitted values. it causes the digestive tract. the nervous system and the cardiovascular and renal arteries. the immunological and humoral mechanisms. The tables indicate an amount of less than $0.01 \mathrm{mg} / \mathrm{kg} \mathrm{d} . \mathrm{w}$. for each food. which is a health benefit. Mercury is a neurotoxic substance. Methyl mercury is a mercury compound involved in changes in the central nervous system. The level of reactive oxygen species increases in toxic amounts of the body and thus makes the link between mercury and Alzheimer disease. This metal also appears in quantities that are not considered toxic. which can be seen in the tables above $(<0.01 \mathrm{mg} / \mathrm{kg}$ d.w. $)[33]$.

Manganese is also a heavy metal in foods associated with neurodegenerative disorders of the central nervous system. The formation of the plaque is associated with the deregulated manganese metabolism. Among the subjects of the experiment. strawberries are carriers of an increased amount of manganese [34]. Besides the determined metals. a few minerals essential to the health of the body ( $\mathrm{Ca}(\mathrm{II}) . \mathrm{Mg}(\mathrm{II})$. $\mathrm{Na}(\mathrm{I})$. and $\mathrm{K}(\mathrm{I})$ ) have been found and as the tables indicate. the highest content of these varies according to the method by which it was determined.

\section{Conclusions}

Alzheimer's disease has many possible causes which have generated it without knowing at this time what are the real causes. But definitely the metals present in food can be an important factor which can be taken into account. The purpose of these techniques is to highlight the correlation between contaminated metals food and neurological diseases.

As a result of the body's inability to remove metals ingested by eating they can become harmful.

Metals can accumulate in different organs even in the brain resulting in various diseases including Alzheimer.

\section{References}

1.KOEDAM. E.L.. LAUFFER. V.. VAN DER VLIES. A.E.. VAN DER FLIER. W.M.. SCHELTENS. P.. PIJNENBURG. Y.A.. J. Alzheimer's Dis. 19, 2010. p. 1401.

2.HUGHES. T.F.. GANGULI. M.. Curr. Psychiatr. Rev. 5. 2009. p. 73.

3.QUERFURTH. H.W.. LAFERLA. F.M. N. Engl. J. Med. 362. 2010. p. 329.

4.MCKHANN. G.M.. KNOPMAN. D.S.. CHERTKOW. H.. HYMAN. B.T.. JACK. JR. C.R.. KAWAS. C.H.. KLUNK. W.E.. KOROSHETZ. W.J.. MANLY. J.J.. MAYEUX. R.. MOHS. R.C.. MORRIS. J.C.. ROSSOR. M.N.. SCHELTENS. P. CARRILLO. M.C.. THIES. B.. WEINTRAUB. S.. PHELPS. C.H.. Alzheimer Dement. 7. 2011. p. 263.

5.PRILLER C.. BAUER T.. MITTEREGGER G.. KREBS B.. KRETZSCHMAR H.A.. HERMS J.. J. Neurosci 26. 2006. p. 7212.

6.PROKIC. I.. COWLING. B.S.. LAPORTE. J.. J. of Molecular Medicine. 92. no 5. 2014. p. 453.

7.CHEIGNON. C.. TOMAS. M.. BONNEFONT-ROUSSELOT. D.. FALLERF. P.. HUREAU. C.. COLLIN. F.. Alzheimer's disease. 2017. p. 450. 8.FARINA. M.. AVILA. D.S.. ROCHA. D.A.. ASCHNER. J.B.T.. Neurochem. Int.. 62. 2013. p. 575.

9.SOTO-ROJAS. L.O.. DE LA CRUZ-LÓPEZ. F.. TORRES. M.A.O.. VIRAMONTES-PINTOS. A.. DEL CARMEN CÁRDENAS-AGUAYO. M.. MERAZ-RÍOS. M.A.. SALINAS-LARA. C.. FLORÁN-GARDUÑO. B.. LUNA-MUÑOZ. J.. Neuro inflammation and Alteration of the BloodBrain Barrier in Alzheimer's Disease. in: I. Zerr (Ed.). Alzheimer's Disease - Challenges for the Future. In Tech2015. MIGLIORE. L.; COPPEDÈ. F. Environmental-induced oxidative stress in neurodegenerative disorders and aging. Mutat. Res.. 674. 2009. p. 73.

10.STOHS. S.J.. BAGCHI. D.. Free Radic. Biol. Med.. 18. 1995. p. 321.

11.LÓPEZ. E.. ARCE. C.. OSET-GASQUE. M.J.. CAÑADAS. S.. GONZÁLEZ. M.P.. Free Radic. Biol. Med.. 40. 2006. p. 940.

12.BORGES. V.C.. SANTOS. F.W.. ROCHA. J.B.. NOGUEIRA. C.W.. Neurochem. Res.. 2007. 32 . p. 953.

13.ZHU. X.. ZHOU. W.. CUI. Y.. ZHU. L.. LI. J.. XIA. Z.. SHAO. B.. WANG. H.. CHEN. H.. Biochem. Biophys. Res. Commun.. 384. 2009. p. 110 .

14.THEOPHANIDES. T.. ANASTASSOPOULOU. J.. Crit. Rev. Oncol. Hematol.. 42. 2002. p. 57.

15.TISATO. F.. MARZANO. C.. PORCHIA. M.. PELLEI. M.. SANTINI. C.. Med. Res. Rev.. 30. 2010. p. 708.

16.SPISNI. E.. VALERII. M.C.. MANERBA. M.. STRILLACCI. A.. POLAZZI. E.. MATTIA. T.. GRIFFONI. C.. TOMASI. V.. Neurotoxicology. 30. 2009. p.605. 
17.ALCARAZ-ZUBELDIA. M.. BOLL-WOEHRLEN. M.C.. MONTES-LÓPEZ. S.. PÉREZ-SEVERIANO. F.. MARTÍNEZ-LAZCANO. J.C.. DÍAZ-RUIZ. A.. RÍOS. C.. Rev. Investig. Clin.. 61.2009. p. 405.

18.MOHAMED. H.H.. ALI. KHAIRIA M.. AL-QAHTANI. The Egyptian Journal of Aquatic Research. 38. no 1. 2012 . p. 31.

19.XINGMEI. L.. SONG. Q.. TANG. Y.. LI. W.. XU. J.. WU. J.A.. WANG. F.. BROOKES. P.C.. 463-464. no 1. 2013. p. 530.

20.ZHENG. N.. WANG. Q.C.. ZHENG. D.M.. Sci .Total Environ. 383. 2007. p. 81.

21.ARULKUMAR. A.. PARAMASIVAM. S.. RAJARAM. R.. Southeastern India. 2017. 119. nr. 1. p. 454.

22.GIAMPIERI. F.. ALVAREZ-SUAREZ. J.M.. GASPARRINI. M.. FORBES- HERNANDEZ. T.Y.. AFRIN. S.. BOMPADRE. S.. RUBINI. C.. ZIZZI. A.. ASTOLFI. P.. SANTOS-BUELGA. C.. GONZÁlEZ-PARAMÁS. A.M.. QUILES. J.L.. MEZZETTI. B.. BATTINO. M.. 94. 2016. p. 128.

23.HU. N.. YU. J.T.. TAN. L.. WANG. Y.L.. SUN. L.. TAN. L.. BioMed Research International. Article ID 524820. 2013. p. 1.

24.BREWER. G.J.. Clin Neurophysiol.. 121. nr 4. 2010. p. 459.

25.*** Institute of Medicine. Dietary Reference Intakes for Vitamin A. Vitamin K. Arsenic. Boron. Chromium. Copper. Iodine. Iron. Manganese. Molybdenum. Nickel. Silicon. Vanadium. and Zinc. National Academy Press: Washington DC. 2001.

26.CHASAPIS. C.T.. LOUTSIDOU. A.C.. SPILIOPOULOU. C.A.. STEFANIDOU. M.E.. Arch Toxicol.. 86. nr 4. 2012. p. 21.

27.BHOWMIK. D.. CHIRANJIB. K.P.. KUMAR. K.P.S.. Int J Pharm Biomed Sci.. 1. nr. 1. 2010. p. 5.

28.NGUYEN. M.. HUANG. M.. LIU. Y.. MEUNIER. B.. ROBERT. A.. Comptes Rendus Chimie. 20. nr. 11-12. 2017. p. 987.

29.PACINI. S. FIORE. MG. MAGHERINI. S. MORUCCI. G. BRANCA. JJ. GULISANO. M. RUGGIERO. M.. Med Hypotheses.. 79. nr. 3. 2012. p. 403.

30.WILBUR. S.. ABADIN. H.. FAY. M.. YU. D.. TENCZA. B.. INGERMAN. L.. KLOTZBACH. J.. JAMES. S.. 2012 Sep. Agency for Toxic Substances and Disease Registry (ATSDR) Toxicological Profiles.

31. FERNANDES AZEVEDO. B.. BARROS FURIERI. L.. PEÇANHA. F. M.. WIGGERS. G. A.. FRIZERA VASSALLO. P.. RONACH ER SIMÕES. M.. FIORIM. J., ROSSI DE BATISTA. P., FIORESI. M., ROSSONI. L.. STEFANON. I., JESUS ALONSO. M.. SALAICES. M.. VASSALLO. D. V.. J. Biomed Biotechnol.. 2012: 949048. p. 2012.

32.DU. K.. LIU. M.. PAN. Y.. ZHONG. X.. WEI. M.. Nutrients.. 9. no 3. 2017. p. 231.

Manuscript received:11.02.2019 